\title{
EHMTI-0267. Plasma anandamide concentration after aerobic exercise training in healthy individuals and episodic migraine patients
}

\author{
AB Oliveira ${ }^{1 *}$, RT Ribeiro ${ }^{1}$, MT Mello², S Tufik², MFP Peres ${ }^{1}$ \\ From 4th European Headache and Migraine Trust International Congress: EHMTIC 2014 \\ Copenhagen, Denmark. 18-21 September 2014
}

\section{Introduction}

Anandamide (AEA) is an endocannabinoid operative in several biological functions. Nevertheless, it is not known the effect of aerobic exercise training (EXT) on plasma $[\mathrm{AEA}]$.

\section{Aims}

Because a dysfunctional endocannabinoid system has been suggested to underlie migraine $(\mathrm{M})$ pathophysiology, we intended to explore the plasma [AEA] after EXT in $M$ patients and healthy individuals.

\section{Methods}

EXT protocol consisted of 12-week of supervised treadmill at standardized intensity, performed 3 times/week, $30 \mathrm{~min} . / \mathrm{session}$. Four groups were separated for intervention or waiting list: Healthy subjects without AET (CC), healthy subjects undergoing EXT (CEXE), $M$ patients without EXT (MC), and M patients undergoing EXT (MEXE). Patients had episodic migraine with and without aura (ICHDII). Blood collections were performed interictally at least $24 \mathrm{~h}$ after attacks or antiinflammatory use. AEA was quantified by LC/MS/MS. All participants took no preventive medication.

\section{Results}

The study included 48 participants (12 for each group) and groups matched by age, sex, and BMI. Baseline [AEA] was not different between groups. AEA reduced in MEXE and CEXE, but was statistically significant only in CEXE $(p=0.007)$. There was a trend to a negative correlation between adherence and $\triangle$ AEA $(r=-0.565, \mathrm{p}=0.056)$.

${ }^{1}$ Neurologia and Neurocirurgia, Universidade Federal de São Paulo, São Paulo, Brazil

Full list of author information is available at the end of the article

\section{Conclusions}

Plasma AEA decreases after EXT in healthy subjects. In $M$ patients, this response is prevented by lower adherence. Future studies should investigate the relationship between exercise-reward and AEA.

* $\mathrm{p}=0.007$, Friedman's Test

No conflict of interest.

\section{Authors' details}

${ }^{1}$ Neurologia and Neurocirurgia, Universidade Federal de São Paulo, São Paulo, Brazil. ${ }^{2}$ Ssicobiologia, Universidade Federal de São Paulo, São Paulo, Brazil.

Published: 18 September 2014

doi:10.1186/1129-2377-15-S1-E22

Cite this article as: Oliveira et al:: EHMTI-0267. Plasma anandamide concentration after aerobic exercise training in healthy individuals and episodic migraine patients. The Journal of Headache and Pain 201415 (Suppl 1):E22.

Submit your manuscript to a SpringerOpen ${ }^{\odot}$ journal and benefit from:

- Convenient online submission

- Rigorous peer review

- Immediate publication on acceptance

- Open access: articles freely available online

- High visibility within the field

- Retaining the copyright to your article

Submit your next manuscript at $\gg$ springeropen.com
(C) 2014 Oliveira et al; licensee Springer. This is an Open Access article distributed under the terms of the Creative Commons Attribution License (http://creativecommons.org/licenses/by/2.0), which permits unrestricted use, distribution, and reproduction in any medium, provided the original work is properly cited. 